\title{
Jaringan Komunikasi Tentang Adopsi Inovasi Tabungan "Simpel” iB (Islamic Banking) SMK Batik Kelas X.A
}

\author{
${ }^{1 *}$ Yulindha Permatasari, ${ }^{2}$ Sutopo, ${ }^{3}$ Ign. Agung Satyawan \\ 1,2,3 Program Pasca Sarjana Ilmu Komunikasi, Universitas Sebelas Maret, Indonesia \\ *Email korenpondensi: lindapermata.lp@gmail.com
}

\begin{abstract}
Simple" savings are a new idea among students, so the decision to adopt an innovation requires the role of individuals and social networks. The communication process that occurs between individuals who are members of a group forms a flow of information exchange that is patterned and forms a communication network. As a result of interactions that occur in the communication network there is an exchange of information about innovations which then affect the adoption process. After an analysis, it was concluded that the process of adoption of innovation in SMK BATIK Surakarta was included in the medium and high categories. It can be seen that in the initial stage of knowledge where students of SMK BATIK Surakarta begin to realize the innovation of the "Simple" savings program iB BPR Syariah Syariah Mulia, knowing their functions, benefits and prerequisites, $73 \%$ of students at SMK BATIK 1 Surakarta are in the high category, while $27 \%$ of group members are in the medium category. After understanding the innovation of the iB BPR Syariah Dana Mulia "Simple" savings program, the next stage of persuasion takes place where students of SMK BATIK 1 Surakarta begin to determine their attitude to accept or reject the innovation of the "Simple" iB BPR Syariah Dana Mulia savings program. The percentage of students who are still hesitant to accept the "Simpel" $i B$ BPR Syariah Dana Mulia savings program is higher than the percentage of students who receive the "Simpel" iB BPR Syariah Dana Mulia savings program.
\end{abstract}

Keywords: Communication Networks, Adoption of Innovations, Islamic Banking

Saran sitasi: Santosa, H., \& Wisnu, A. (2019). Jaringan Komunikasi Tentang Adopsi Inovasi Tabungan "Simpel” iB (Islamic Banking) SMK Batik Kelas X.A. Jurnal Ilmiah Ekonomi Islam, 5(03), 292-306. doi: http://dx.doi.org/10.29040/jiei.v5i3.723

DOI: http://dx.doi.org/10.29040/jiei.v5i3.723

\section{Pendahuluan}

Tabungan Simpanan Pelajar "simpel" merupakan tabungan untuk siswa yang diterbitkan secara nasional oleh bank-bank di Indonesia dengan persyaratan mudah dan sederhana serta fitur yang menarik. dan inklusi keuangan Dalam rangka edukasi untuk mendorong budaya manabung sejak dini. Produk Tabungan "simpel" pada BPR Syari'ah Dana Mulia ini memiliki setoran awal lebih ringan yaitu minimal $\mathrm{Rp}$ 5.000, Minimal setoran selanjutnya Rp 1.000 dan Saldo minimum Rp
5.000. Produk tabungan "simpel" ini masih dikatakan masih baru karena produk ini direalisasikan pada tahun 2016, tetapi antusias pelajar sangat bagus dan dibuktikan dengan bertambahnya nasabah pada setiap tahunnya. Tabungan "simpel" merupakan suatu gagasan baru di kalangan pelajar secara langsung. Gagasan baru ini dapat dikatakan sebagai inovasi Inovasi mempunyai arti sesuatu yang baru. Sesuatu dikatakan baru apabila (1) menciptakan sesuatu yang baru, yang sebelumnya belum ada, (2) menciptakan sesuatu yang baru dari yang 
sudah ada, (3) memperbaruhi sesuatu dari yang sudah ada. Dalam penelitian ini yang dimaksud dengan inovasi adalah tabugan "simpel" yang berbasis Islamic Banking. Inovasi ini diperkenalkan di SMK Batik 1 Surakarta. Dalam proses penyebaran inovasi, komunikasi mempunyai peranan penting. Melalui komunikasi yang efektif, informasi tentang inovasi bisa diterima dan dipahami oleh siswa dan siswi dengan baik sehingga pemanfaatannya bias optimal.

Keputusan mengadopsi suatu inovasi terjadi melalui proses yang melibatkan peran individual dan jaringan social. Penelitian ini mengamati peran nasabah sangat menentukan perilaku adopsi inovasi. Proses komunikasi yang terjadi antara individu-individu yang tergabung dalam kelompok membentuk arus pertukaran informasi yang terpola dan membentuk suatu jaringan komunikasi. Akibat dari interaksi yang terjadi dalam jaringan komunikasi kelompk terjadilah pertukaran informasi tentang inovasi yang kemudian mempengaruhi proses adopsi. Jaringan komunikasi juga bisa menunjukan orang-orang yang mempunyai peranan penting dalam kelompok jaringan komunikasi.

Jaringan komunikasi merupakan suatu rangkaian yang menghubungkan orang-orang dalam suatu masyarakat yang menunjukan siapa yang berkomunikasi secara teratur, berapa besar jaringan itu atau berapa banyak anggota yang dihubungkannya, bagaimana arus komunikasinya "mengalir" melalui jaringan itu serta bagaimana kedudukan masing-masing orang di dalamnya. Kedudukan individu didalam kelompok, seperti pemimpin memiliki peran yang penting karena menentukan kuantitas dan kualitas komunikasi dalam kelompok tersebut. Salah satu fungsi dari kepemimpinan adalah sebagai penyaring sekaligus penyebar informasi. Pada kelompok nasabah di SMK Batik 1 Surakarta ini juga tidak terlepas dari peran seseorang sebagai opinion leader dalam memilih tabungan "simpel" yang terdapat pada BPR Syari'ah Dana Mulia. Peran opinion Leader yaitu seseorang yang merupakan pemusatan jalur komunikasi dari beberapa orang.
Dalam sebuah Kelompok, untuk membentuk suatu jaringan kamunikasi tidak hanya peran opinion leader saja, namun peran penghubung (liaison), pemencil (isolate) dan jembatan (brigde). Peran-peran inilah yang membuat terbentuknya jaringan kelompok nasabah di SMK Batik 1 Surakarta. Melalui jaringan ini lah, kelompok nasabah pada SMK BATIK 1 Surakarta ini akan terlihat siapa mempengaruhi siapa dalam pemilihan produk perbankan di BPR Syari'ah Dana Mulia.

Penelitian ini memiliki tiga tujuan, yaitu : 1) untuk mengetahui pola jaringan komunikasi pada kelas X.4 di SMK Batik 1 Surakarta dalam proses adopsi inovasi tabungan "simpel"; 2) untuk mengidentifikasi peran-peran khusus yang terdapat dalam struktur jaringan komunikasi yang terbentuk; dan 3) untuk mengetahui pengaruh jaringan komunikasi dalam kelompok dalam jumlah tabungan.

Beberapa penelitian yang relevan dengan penelitian ini adalah:

Penelitian ini ditulis oleh Zulfikar, M.Iqbal Sultan dan Jeanny Maria Fatimah dari Fakultas Psikologi Universitas Indonesia Timur Makassar dan Jurusan Ilmu Komunikasi Universitas Hasanudin Makassar tahun 2013. Penelitian ini menggunakan pendekatan metode kuantitatif dan kualitatif. Desain penelitian yang digunakan dalam penelitian ini adalah regresi liniear sederhana dan pendekatan kuantitaif dilakukan dengan mewawancarai ketua lembaga dan koordinator aksi atau jendral lapangan untuk mengetahui jenis pola komunikasi yang digunakan dalam menumbuhkan solidaritas aksi unjuk rasa mahasiswa di kota Makassar. Hasil penelitian ini menyatakan bahwa jaringan komunikasi mempunyai pengaruh dalam menumbuhkan solidaritas aksi unjuk rasa mahasiswa, Pada kelompok organisasi mahasiswa yang diteliti terdapat dua jenis pola jaringan komunikasi yang digunakan dalam menumbuhkan soliaritas mahasiswa yaitu model jaringan rantai (chin) dan model jaringan bebas (all-channel). 
Penelitian ini ditulis oleh Parlaungan Adil Rangkuti dari Fakultas Teknologi Pertanian, Institut Pertanian Bogor. Penelitian ini memeliti tentang penggunan traktor tangan di Indonesia yang terus meningkat karena makin terbatasnya waktu, serta tenaga kerja manusia dan ternak untuk mengelola lahan,sawah. Salah satu permasalahannya adalah bahwa proses adopsi inovasi traktor tangan masih rendah karena peran jaringan komunikasi petani yang belum dinamis. Hasil penelitian ini menunukkan bahwa dalang sosiometri jaringan komunikasi, interaksi komunikasi dalam adopsi inovasi traktor tangan membentuk jaringan yang cenderung terbuka, berbentuk bintang atau roda. Jaringan komuniaksi petani dalam kaitannya dengan nilai keterkaitan, keragaman, kekompakkan dan keterbukaan kelompok tani, secara umum masih tergolong sedang dan rendah.

Jurnal penelitian ini disusun oleh Alfi Rahmawati Sekolah Pascasarjana Institu Pertanian Bogor tahun 2016. Penelitian ini menganggkat kabupaten Magetan yang memiliki potensi Kabupaten Magetan memiliki potensi sebagai sentra produksi jeruk pamelo di Indonesia, namun kendala dalam produksi dan pemasaran jeruk pamelo adalah kurangnya ketersediaan informasi terbaru mengenai teknologi budidaya dan pemasaran yang dapat mendukung petani. Petani hanya mengandalkan pengetahuan budidaya pamelo secara konvensional yang diperoleh secara turun temurun. Penelitian ini menggunakan metode free recall untuk menganalisis jaringankomunikasi antar petani jeruk pamelo, dimana responden diminta mengingat (recall) dan menyebutkan dengan siapa ia berkomunikasi atau memperoleh informasi mengenai pemasaran jeruk pamelo. Hasil penelitian ini menunjukkan bahwa aktor yang berperan penting dalam diseminasi informasi penanaman jeruk pamelo di Desa Tambak Mas adalah PPL. Pada jaringan diseminasi informasi pemeliharaan jeruk pamelo, mantri tani, PPL, dan ketua Poktan Sekar Mulyo merupakan aktor sentral yang dijadikan rujukan. Sedangkan pada diseminasi informasi pemasaran tengkulak merupakan aktor sentral dalam jaringan. Analisis jaringan komunikasi pada kelompok tani menggambarkan struktur komunikasi yang berbeda antar kelompok, secara umum aktor sentral dalam kelompok adalah ketua poktan. Kohesivitas kelompok (densitas) tertinggi umumnya terjadi dalam diseminasi informasi pemeliharaan jeruk pamelo.

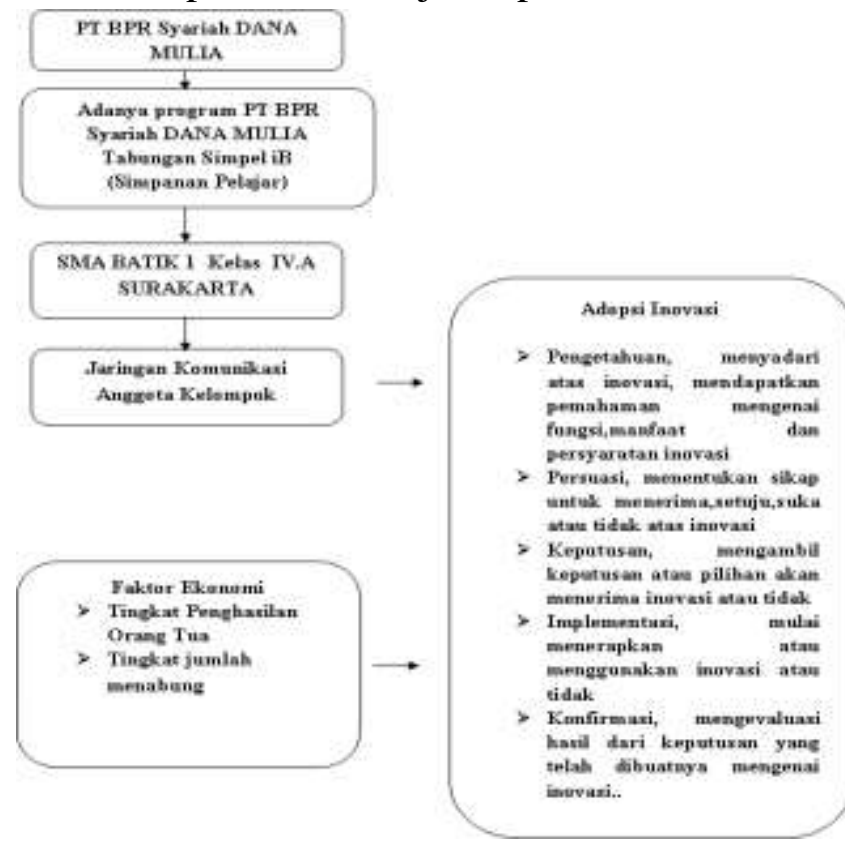

\section{Metode Penelitian}

Penelitian yang akan penulis lakukan menggunakan pendekatan metodologi kuantitatif metode survey dengan pengumpulan data menggunakan kuesioner dan teori analisis jaringan komunikasi untuk mengidentifikasi struktur jaringan komunikasi ada SMK Batik 1 Surakarta tentang adopsi inovasi tabungan "simpel". Tujuan dari dilaksanakannya penelitian ini yaitu untuk menganalisis peran komunikasi kelompok nasabah dalam jaringan komunikasi. Penelitian ini diharapkan bermanfaat sebagai pertimbangan dalam penentuan pemilihan perbankan.

\section{Hasil dan Pembahasan}

3.1. Identifikasi Responden Terkait Jaringan Komunikasi Tentang Adopsi Inovasi Tabungan "Simpel" iB (Islamic Banking) BPR Syariah Dana Mulia di SMK Batik 1 Surakarta 
Pada aspek karakteristik responden (aktor) diketahui bahwa yang paling dominan tingkat pekerjaan orang tua adalah karyawan swasta dan wiraswasta yang masing masing sebesar dan $52 \%$ dan $40 \%$, hal ini karena tempat tinggal mereka rata-rata diperkotaan maka yang berprofesi sebagai petani tidak ada. Dengan jumlah menabung yang paling dominan adalah kurang dari $\mathrm{Rp} 10.000$ hal ini mencerminkan bahwa yang ditabung merupakan uang saku yang diberikan oleh orang tua apalagi dilakukannya setiap hari, meskipun demikian ada yang menabung antara Rp 50.000 sampai dengan Rp 100.000 yang dilakukan setiap minggu.

Berdasarkan pada karakteristik tersebut maka dapat dikatakan bahwa tingkat sosial ekonomi (SES) para responden adalah masuk dalam kategori menengah kebawah. Namun apabila dikaitkan dengan tingkat adopsi inovasi Tabungan "Simpel” iB (Islamic Banking) BPR Syariah Dana Mulia di SMK BATIK 1 Surakarta pada aspek-aspek pengetahuan, persuasi, keputusan\& implementasi, dan konfirmasi yang dominan pada kategori tinggi maka dapat dipahami bahwa ada kesadaran dari para aktor yaitu siswa SMK Batik 1 Surakarta yang cukup tinggi untuk menabung terutama Tabungan "Simpel" iB (Islamic Banking) BPR Syariah Dana Mulia karena adanya kesadaran akan manfaat dari menabung yang bisa digunakan pada saat membutuhkan.
3.2. Pola Jaringan Komunikasi Tentang Adopsi Inovasi Tabungan "Simpel" iB (Islamic Banking) BPR Syariah Dana Mulia di SMK BATIK 1 SURAKARTA

Identifikasi struktur jaringan komunikasi kelompok Adopsi Inovasi Tabungan "Simpel” iB (Islamic Banking) BPR Syariah Dana Mulia dimulai dengan mengamati pilihan komunikasi antar anggota yang dituangkan dalam table pilihan komunikasi. Table iniberisi nama-nama anggota kelompok, berikut pilihan masingmasing anggota terhadap anggota yang lain.

Pada kelompok Adopsi Inovasi Tabungan "Simpel" iB (Islamic Banking) BPR Syariah Dana Mulia terdari dari 25 siswa. Setiap anggota kelompok disebut sebagai actor diberi symbol \#(actor) dari 1 sampai dengan 25. Setiap actor diminat menyebutkan (memilih) 3 aktor lain yang sering dihubungi unuk dimintai pendapat, diajak diskusi atau sebagai tempat untuk bertanya tentang Adopsi Inovasi Tabungan "Simpel" iB (Islamic Banking) BPR Syariah Dana Mulia.

Matrik sosiometri menunjukkan hubungan memilih dan dipilih dalam jaringan komunikasi dari setiap anggota kelompok. Lajur vertical (baris) merupakan lajur memilih sementara lajur horizontal (kolom). Untuk lajur vertical (baris) merupakan lajur memilih dan di pilih dalam jaringan komunikasi dari setiap anggota kelompok. Lajur vertical (baris) merupakan lajur memilih, sementara lajur horisontal (kolom merupakan lajur dipilih.

Tabel. Pilihan komunikasi anggota kelompok Adopsi Inovasi Tabungan "Simpel” iB (Islamic Banking) BPR Syariah Dana Mulia

\begin{tabular}{|c|c|c|c|c|}
\hline \multirow{2}{*}{ Resp } & \multicolumn{2}{|c|}{ Memilih } & Dipilih & Cacah \\
\cline { 2 - 5 } & Aktor & Cacah & $\# 13, \# 15, \# 22$ & 3 \\
\hline p01 & $\# 13, \# 15, \# 22$ & 3 & $\#$ (15, & 12 \\
\hline p02 & $\# 11, \# 16, \# 17$ & 3 & $\# 3, \# 4, \# 5, \# 11, \# 14, \# 16, \# 17, \# 18, \# 19, \# 20, \# 23,2 \# 4$ & 2 \\
\hline p03 & $\# 2, \# 4, \# 9$ & 3 & $\# 4, \# 9$ & 2 \\
\hline p04 & $\# 2, \# 3, \# 9$ & 3 & - & 0 \\
\hline p05 & $\# 2, \# 13, \# 22$ & 3 & $\# 16$ & 1 \\
\hline p06 & $\# 10, \# 13, \# 22$ & 3 & $\# 21$ & 1 \\
\hline p07 & $\# 10, \# 12, \# 20$ & 3 & $\# 22, \# 23$ & 2 \\
\hline p08 & $\# 10, \# 16, \# 22$ & 3 & $\# 3, \# 4, \# 18, \# 24, \# 25$ & 5 \\
\hline p09 & $\# 3, \# 4, \# 16$ & 3 & & \\
\hline
\end{tabular}


Jurnal Ilmiah Ekonomi Islam, 5(03), 2019, 296

\begin{tabular}{|c|c|c|c|c|}
\hline \multirow{2}{*}{ Resp } & \multicolumn{2}{|c|}{ Memilih } & Dipilih & Aktor \\
\cline { 2 - 5 } & Aktor & Cacah & $\#$ Cah \\
\hline p10 & $\# 20, \# 21, \# 23$ & 3 & $\# 6, \# 7, \# 8, \# 12, \# 17, \# 19, \# 20, \# 21, \# 23, \# 24, \# 25$ & 11 \\
\hline p11 & $\# 2, \# 12, \# 21$ & 3 & $\# 2, \# 14, \# 18$ & 3 \\
\hline p12 & $\# 10, \# 19, \# 22$ & 3 & $\# 7, \# 11, \# 13$ & 3 \\
\hline p13 & $\# 1, \# 12, \# 22$ & 3 & $\# 1, \# 5, \# 6, \# 15, \# 20, \# 22$ & 7 \\
\hline p14 & $\# 2, \# 11, \# 22$ & 3 & - & 0 \\
\hline p15 & $\# 1, \# 13, \# 22$ & 3 & $\# 1$ & 1 \\
\hline p16 & $\# 2, \# 6, \# 17$ & 3 & $\# 2, \# 8, \# 9, \# 17$ & 4 \\
\hline p17 & $\# 2, \# 10, \# 16$ & 3 & $-\# 2, \# 16$ & 2 \\
\hline p18 & $\# 2, \# 9, \# 11$ & 3 & - & 0 \\
\hline p19 & $\# 2, \# 10, \# 22$ & 3 & $\# 12$ & 1 \\
\hline p20 & $\# 2, \# 10, \# 13$ & 3 & $\# 10, \# 11$ & 3 \\
\hline p21 & $\# 7, \# 10, \# 20$ & 3 & $\# 10, \# 21$ & 2 \\
\hline p22 & $\# 1, \# 8, \# 13$ & 3 & - & 9 \\
\hline p23 & $\# 2, \# 8, \# 10$ & 3 & - & 1 \\
\hline p24 & $\# 2, \# 9, \# 10$ & 3 & & 0 \\
\hline p25 & $\# 9, \# 10, \# 13$ & 3 & & 0 \\
\hline
\end{tabular}

Pada kelompok siswa SMK BATIK 1 Surakarta mendasari lajur vertical (memilih) dan horizontal (dipilih) terdiri dari 25 responden (anggota kelompok). Angka 1 (satu) dlam matrik menunjukkan adanya hubungan memilih dan dipilih, sementara angka 0 (nol) menunjukkan tidak adanya hubungan diantara keduanya.

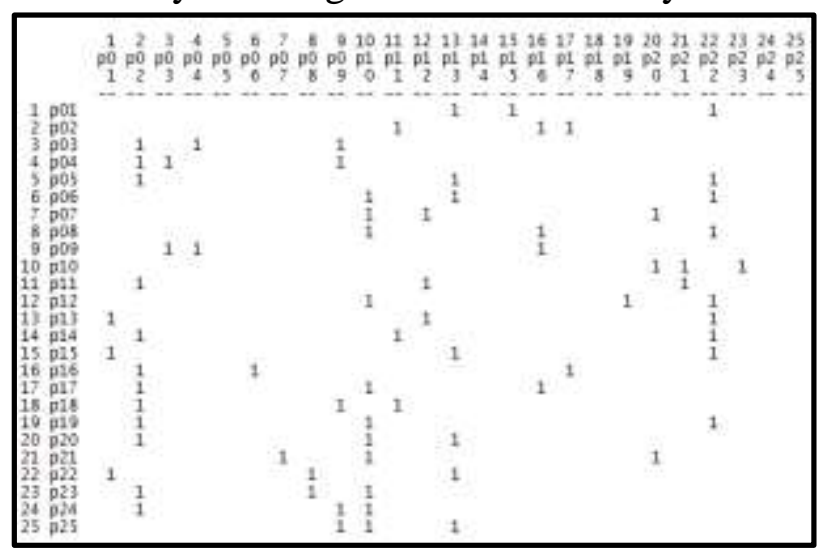

Gambar... Matrik Sosiometri Kelompok

Sumber : data diolah tahun 2019 dengan Program UNICET 6.0

Setelah terbentuk matrik sosiometri seperti diatas, selanjutnya dapat disusun diagram sosiometri (sosiogram) yang akan memperlihatkan relasi antara satu actor dengan actor yang lain dalam jaringan komunikasi. Sosiogram menunjukkna bagaimana jaringan komunikasi antara individu di dalam kelompok siswa SMK BATIK 1 Surakarta. Hubungan komunikasi antar individu di dalam kelompok disimbolkan dengan panah yang menuju seorang actor (node). Anak panah yang menuju seorang actor dapt diartikan bahwa actor tersebut telah dipilih oleh actor lain. Dengan pilihan trsebut, maka actor pemilih akan mendapatkan informasi dari actor yang dipilih, sehingga arus informasi yang terjadi adalah berlawanan dengan anak panah pilihan, diman seorang actor pemilih akan mendapatkan informasi dari actor yang dipilihnya.

Terapat 6 aktor (24\%) anggota kelompok siswa SMK BATIK 1 Surakarta yang dipilih oleh banyak actor di dalam kelompok ini, yaitu individu \#02, \#10, \#22, \#13, \#09, \#16. Hal ini menunjukkan ada 6 (enam) sumber informasi dalam kelompok yang dijadikan rujukan, menjadi tempat bertanya bagi anggota yang alinnya. Individu \#02 adalah yang paling banyak dipilih oleh anggota, yaitu sebanyak 12 pemilih, disusul actor \#10 sebanyak 11 pemilih, actor \#22 sebanyak 9 pemilih, actor \#13 sebanyak 7 pemilih, actor \#9 sebanyak 5 pemilih, dan actor \#16 sebanyak 4 pemilih. 
Selain itu, sebanyak 5 orang (20\% anggota) yang masuk dalam kategori peran neglectee yaitu aktor yang memilih tetapi tidak dipilih seorangpun di dalam jaringan. Hal ini menunjukkan orang-orang tersebut pernah membicarakan tentang tabungan "Simpel" iB (Islamic Banking) BPR Syariah Dana Mulia kepada aktor lain untuk mendapatkan informasi, tetapi tidak pernah diajak bicara atau dijadikan tempat bertanya oleh aktor lain dalam jaringan.

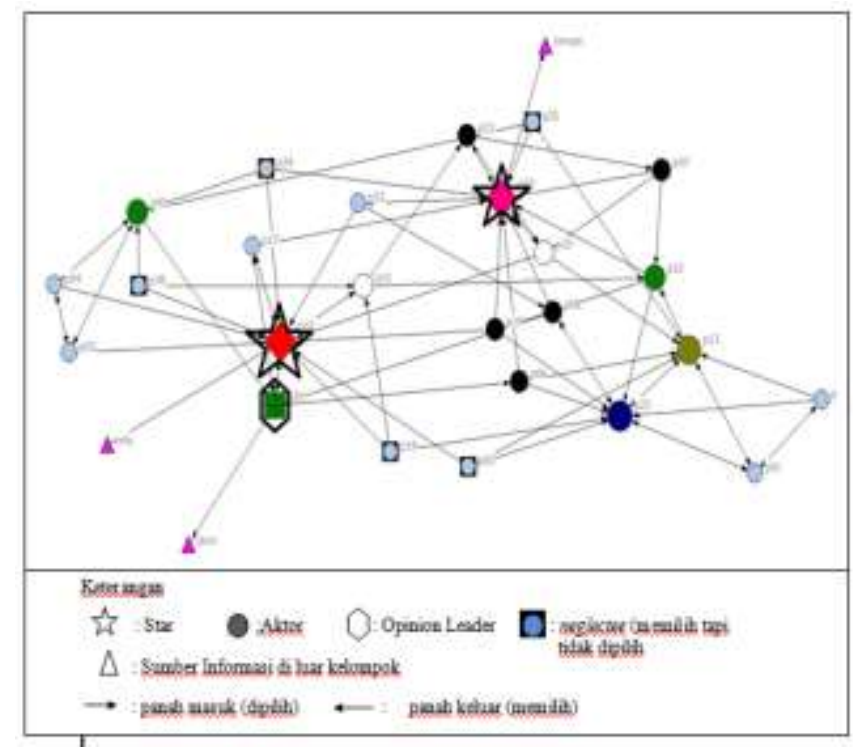

Untuk mengetahui lebih jauh terhadap posisi aktor dalam jaringan dapat dilihat dari beberapa indicator berikut ini:

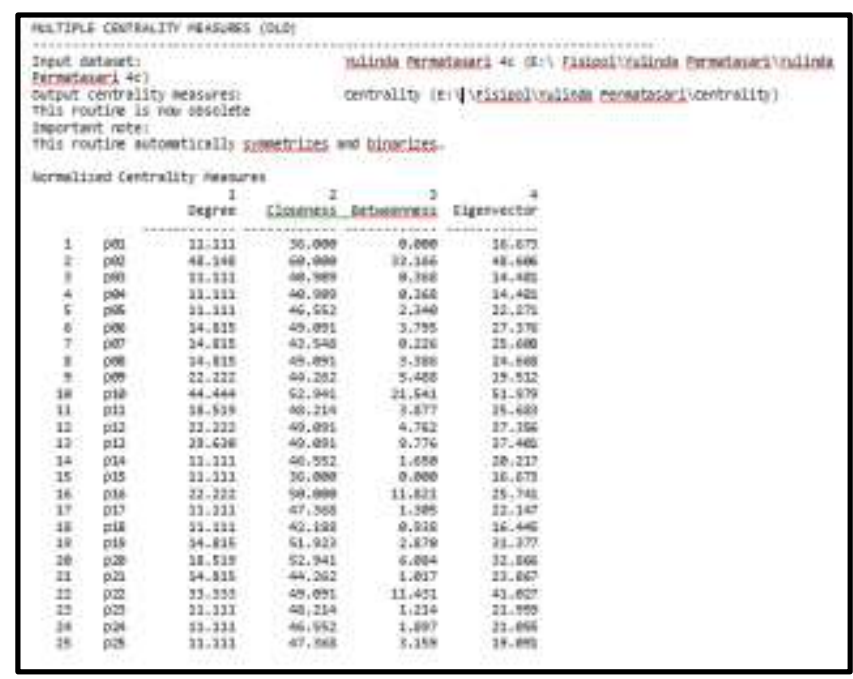

Gambar.... Hasil Pengolahan Data Sosiometri Kelompok siswa SMK BATIK 1 Surakarta

Sumber : data diolah tahun 2019, dengan program UNICET 6.0
Popularitas aktor dlam jaringan komunikasi kelopok siswa SMK BATIK 1 Surakarta dapat dilihat dari 4 (empat) indicator seperti pada Gambar.... Diatas, yaitu:

a. Sentralitas tingkatan (degree centrality), semakin besar nilainya maka aktor tersebut semakin popular. Dari 6 (enam) aktor yang disebutkan diatas, aktor \#2 mendapatkan nilai degree centrality sebesar 48,148\% disusul aktor \#10 sebesar 44,444\%, aktor \#22 sebesar 33,333\%, aktor \#13 sebesar $29,630 \%$, aktor \#9 sebesar $22,222 \%$, aktor \#16 sebesar 22,222\%. Angka ini menunjukkan bahwa aktor \#2 merupakan aktor terpopuler di kelompok siswa SMK BATIK 1 Surakarta sebagai tempat bertanya dan rujukan dalam menabung di tabungan "Simpel" iB (Islamic Banking) BPR Syariah Dana Mulia, sehingga aliran informasi dari aktor \#2 sedikit banyak akan mewarnai pola menabung di kelompok ini.

b. Sentralitas kedekatan (closeness centrality), semakin besar nilai menggambarkan seorang aktor mempunyai tingkat kedekatan yang lebih terhadap kelompoknya. Aktor \#2 mempunyai nilai tertinggi yaitu $60 \%$ disusul aktor \#10 dan aktor \#20 masing-masing mempunyai nilai closeness centrality sebesar 52,9

c. Sentralitas keperantaraan (betweenness centrality) menunjukkan peran aktor sebagai perantara dalam jaringan. Makin tinggi nilai betweenness, maka aktor memiliki peran yang lebih besar sebagai perantara dalam jaringan. Aktor yang dipilih banyak orang belum tentu mempunyai nilai keperantaraan yang tinggi, tetapi dalam kasus jaringan siswa SMK BATIK 1 Surakarta aktor \#2 juga memiliki nilai betweenness centrality yang paling besar yaitu sebesar 33,2 \%, disusul aktor \#10 sebesar 21,5\% .

d. Sentralits eigenvector, menunjukkan seberapa penting orang yang berhubungan dengan jaringan. Aktor \#10 mempunyai nilai sebesar 52\% tertinggi diantara aktor-aktor yang lain. 
Tabel. Presentase Aktor menurut Kategori Sentralitas pada Jaringan siswa SMK BATIK 1 Surakarta

\begin{tabular}{ccccc}
\hline Kategori & $\begin{array}{c}\text { Degre } \\
\mathrm{e}\end{array}$ & $\begin{array}{c}\text { Closene } \\
\text { ss }\end{array}$ & $\begin{array}{c}\text { Betwee } \\
\text { nness }\end{array}$ & $\begin{array}{c}\text { Eigenv } \\
\text { ector }\end{array}$ \\
\hline$(1)$ & $(2)$ & $(3)$ & $(4)$ & $(5)$ \\
\hline Rendah & 92 & 0 & 100 & 80 \\
sedang & 8 & 100 & 0 & 20 \\
Tinggi & 0 & 0 & 0 & 0 \\
\hline \multicolumn{2}{c}{ Sumber : diolah tahun 2019. Dengan program }
\end{tabular}
UNICET 6.0

Apabila dikategorikan, sekitar maka 68\% aktor memiliki sentralitas yang rendah. Hal ini dpat diartikan bahwa sebagian besar aktifitas komunikasi siswa SMK BATIK 1 Surakarta hanya didominasi oleh sekitar 32\% anggotanya. Agar kelompok siswa SMK BATIK 1 Surakarta lebih dinamis maka peran anggota perlu ditingkatkan. Keaktifan anggota dalam kelompok diharapkan dapat menumbuhkan semangat siswa dalam menabung ditabungan "Simpel" iB (Islamic Banking) BPR Syariah Dana Mulia.

Berdasarkan diagram sosiometri dan 4 (empat) indicator tersebut, dapat disimpulkan bahwa aktor \#2 dan aktor \#10 merupakan star alam jaringan komunikasi siswa SMK BATIK 1 Surakarta. Kedua tokoh/ aktor ini telah menabung ditabungan "Simpel" iB (Islamic Banking) BPR Syariah Dana Mulia dengan nominal yang cukup besar bagi seorang siswa yaitu diatas $\mathrm{Rp} 50.000$ per minggu.

Peran lain yang dapat terdeteksi adalah opinion leader yaitu aktor \#16, yang memiliki nilai keperantaraan sebesar $11,4 \%$. Berikut ini profil opinion leader dalam jaringan. Selain beberapa ukuran pada level aktopr diatas, penelitian ini juga menganalisis jaringan pada level sisite, yaitu melalui ukuran kepadatan jaringan/density. Kepadatan jaringn adalah perbndingan antara jumlah link (ties) dengan jumlah link yang mungkin muncul. Density padakelompok siswa SMK BATIK 1 Surakarta menunjukkan prosentse 0,52 atau $52 \%$ sebagaimana pada gambar berikut:

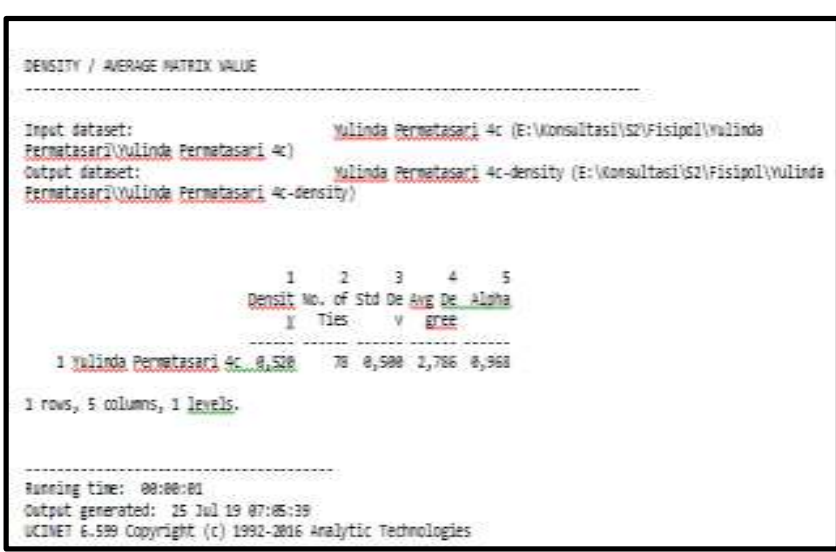

Gambar. Indikator Density Jaringan Komunikasi Siswa SMK BATIK 1 Surakarta

Sumber: data diolah tahun 2019, dengan program UNICET 6.0

Ukuran ini menunjukkan bahwa kepadatan jaringan cukup tinggi, artinya masih dimungkinkan adanya koneksi aktor-aktor dalam jaringan untuk saling terhubung satu sama lain. Hal ini bukan berarti para aktor tidak saling mengenal, akan lebih pada menunjukkan terjadinya pemusatan informasi mengenai menabung ditabungan "Simpel" iB (Islamic Banking) BPR Syariah Dana Mulia pada sebagian orang saja di dalam jaringan. Hal ini bias dipahami karena kebiasaan menabung memang belum menjadi budaya bagi sebagian besar masyarakat terutama anak sekolah pada level sekolah menengah atas (SMA).

Berdasarkan semua ukuran diatas, dapat disimpulkan bahwa pada kelompok jairngan Siswa SMK BATIK 1 Surakarta masih terjadi pemusatan arus informasi di dalam jaringan. Hal ini menjadi indicator untuk memasukkan struktur jaringn kelompok Siswa SMK BATIK 1 Surakarta dalam struktur roda. Devito dalam Sulistyawati (2014) menjelaskan bahwa struktur ini memiliki pemimpin yang jelas yang posisinya berada di pusat jaringan aktor, aktor ini menjadi penerima dan pengirim pesan anggota. Hal ini memudahkan bagi siapa saja yang ingin memberikan informasi, cukup melalui pemimpin kelompoknya.

Jaringan komunikasi tentang adopsi inovasi tabungan Simpel" iB (Islamic Banking) BPR Syariah Dana Mulia di SMK BATIK 1 Surakarta 
dapat ditabulasi dalam bentuk crostabulasi antara Adopsi Inovasi yang meliputi pengetahuan, persuasi, keputusan \& implementasi, dan konfirmasi dengan Jaringan komunikasi yang meliputi : Innovator, Early adopter, Early majority, Late majority, Laggards

\section{Innovator}

Peran Innovator di pegang oleh aktor \#10 yang bernama Safira Ardiana Putri, apabila dikaitkan dengan adopsi inovasi Tabungan "Simpel" iB (Islamic Banking) BPR Syariah Dana Mulia maka aktor memiliki pengetahuan dengan skor 85 kategori tinggi, memiliki persuasi dengan skor 70 kategori tinggi, memiliki keputusan \& implementasi dengan skor 65 kategori sedang, dan memiliki konfirmasi dengan skor 92 kategori tinggi. Sehingga dapat dikatakan bahwa aktor \#10 memiliki tingkatan adopsi kategori tinggi, maka aktor \#10 mampu memperkenalkan adopsi inovasi Tabungan "Simpel" iB (Islamic Banking) secara meluas dalam jaringan siswa SMK Batik 1 Surakarta.

\section{Early Adopter}

Peran Early adopter atau pelopor awal dipegang oleh aktor \#12, \#21. Karakteristik aktor \#12 bernama Shelsy Elza Nora A adalah seorang siswi yang berumur 16 tahun dengan frekuensi menabung tiap bulan dengan nominal diantara Rp 50.000 sampai dengan $\mathrm{Rp} 10.000$ tingkatan adopsi inovasi pada aspek pengetahuan sebesar 75 (tinggi), pengetahuannya tentang tabungan "Simpel" iB (Islamic Banking) BPR Syariah Dana Mulia diperoleh dari orang tua, teman dan sekolah, aktor sangat memahami akan manfaat menabung sehingga berkemampuan untuk menjadi pemuka pendapat dalam system jaringan siswa SMK Batik 1 Surakarta. Kemampuan ini di dukung oleh orangtuanya yang sering mengajak kepada aktor tentang manfaat menabung terbukti aktor selalu menabung dari hasil menyisihkan uang sakunya.

Pengetahuan yang tinggi kemudian diikuti dengan tingkat persuasinya yang tinggi dengan skor sebesar 76,7, hal di dorong oleh kemudahan persyaratan, kemudahan menarik dan tidak ada biaya administrasi di tabungan "Simpel" iB
(Islamic Banking) BPR Syariah Dana Mulia. Kondisi inilah yang membuat aktor kemudian bersikap untuk menabung dan menjadi pelopor bagi siswa-siswa di SMK Batik 1 Surkarta.

Keputusan dan implementasi yang diambil oleh aktor \#12 sebesar 77,5 (kategori tinggi) terbukti langkah dan keputusan yang diambil selalu dikonsultasikan dengan orang tua dan kepala sekolah. Keputusan yang diambil tidak membutuhkan waktu yang lama.

Demikian juga dalam hal melakukan konfirmasi (evaluasi) terhadap langkah-langkah adopsi inovasi ini, aktor \#12 termasuk cepat (kategori tinggi) dalam melakukan evaluasi terbukti merasa puas dan kesediaan untuk tidak berpindah pada tabungan lain. Hal yang memperkuat perannya dalam jaringan sebagai early adopter adalah mengajak temannya untuk menabung

Aktor \#21 bernama Novi Puspita memiliki karakteristik yang hampir mirip dengan aktor \#12, didalam jaringan aktor \#21 memiliki peran sebagai Early adopter atau pelopor awal. Tingkat pengetahuannya sama dengan aktor \#12 namun untuk aspek persuasi, keputusan \& implementasi, dan konfirmasi memiliki skor yang lebih tinggi dibandingkan dengan aktor \#12. 3. Early Majority

Peran Early majority dipegang oleh aktor \#11 yang bernama Silvia Rahmawati, merupakan seorang siswi yang berumur 15 tahun dengan frekuensi menabung setiap hari dan pekerjaan orang tuanya sebagai wiraswasta. Aktor \#11 sangat dekat dengan aktor \#12 dan aktor \#21 karena sering mendapatkan informasi tentang Tabungan "Simpel" iB (Islamic Banking) BPR Syariah Dana Mulia. Hal ini terbukti dari tingkatan adopsi inovasi pada aspek pengetahuan sebesar 75 kategori tinggi, pada aspek persuasi sebesar 76,7 kategori tinggi, aspek keputusan \& implementasi sebesar 77,5 kategori tinggi, dan aspek konfirmasi sebesar 72 kategori tinggi. meskipun aktor \#11 bukan kelompok pertama yang mengadopsi tetapi merupakan pengikut awal namun tingkat penerimaannya terhadap inovasi termasuk dalam kategori tinggi. 
Aspek pengetahuan yang tinggi dikarenakan aktor \#11 sangat mengetahui manfaat menambung dan informasi yang berikan oleh pihak sekolah. Aspek persuasi yang tinggi dikarenakan aktor \#11 merasakan adanya kemudahan persyaratan dengan nominal yang tidak besar serta kemudahan penarikan tanpa biaya administrasi. Aspek keputusan \& implementasi yang tinggi karena sudah mendapatkan persetujuan dari orang tua dengan berkonsultasi kepada kepala sekolah maka aktor \#11 segera membuka rekening tabungan dalam kurun waktu 1 minggu dengan tingkat rutinitas menabung yang tinggi yaitu setiap hari. Aspek konfirmasi yang sangat tinggi karena aktor \#11 merasakan mendapatkan manfaat menabung, merasakan puas dan tidak akan berpindah ke tabungan lain yang diikuti dengan keputusannya yang kuat untuk mengajak aktor lain dala jaringan siswa SMK Batik 1 Surakarta untuk mengikuti jejaknya menabung di tabungan
"Simpel" iB (Islamic Banking) BPR Syariah Dana Mulia

\section{Late Majority}

Peran Late majority dipegang oleh aktor \#18 bernama Yunita Ferdianti adalah individu pengikut akhir penerima inovasi dalam jaringan siswa SMK 1 Batik Surakarta adalah mereka yang berperan sebagai neglectee dengan indeks keterhubungan yang rendah. Dikatakan neglectee karena aktor \#18 memiliki peran memilih (panah keluar) tetapi tidak pernah dipilih (panah masuk). Apabila dilihat karakteristik aktor maka dapat dikatakan bahwa aktor \#18 berhubungan dengan aktor early majority yaitu \#11, \#02 sehingga dalam hal adopsi inovasi tabungan "Simpel" iB (Islamic Banking) BPR Syariah Dana Mulia skor aspek pengetahuan, aspek persuasi, aspek keputusan \& implementasi, dan aspek konfirmasi berada diantara aktor \#11, \#02. Hal ini dapat dilihat dari table berikut:

\begin{tabular}{|l|l|c|c|c|c|}
\hline \multirow{2}{*}{ Aktor } & \multirow{2}{*}{ Nama } & \multicolumn{4}{|c|}{ Skor Aspek Adopsi Inovasi } \\
\cline { 3 - 6 } & & Pengetahuan & Persuasi & $\begin{array}{c}\text { Keputusan \& } \\
\text { Implementasi }\end{array}$ & \multirow{2}{*}{ Konfirmasi } \\
\hline$\# 11$ & Silvia Rahmawati & 80 & 90 & 75 & 100 \\
\hline$\# 18$ & Yunita Ferdianti & 80 & 96,7 & 80,0 & 84 \\
\hline$\# 02$ & Widya Astuti & 85 & 90 & 87,5 & 72 \\
\hline
\end{tabular}

Sumber : data diolah 2019

Berdasarkan tabel tersebut dapat diketahui bahwa hanya apa aspek persuasi, aktor \#18 memiliki skor paling tinggi dibandingkan dengan aktor \#11, \#02 yang menjadi panutannya early majority. Meskipun memiliki peran Late majority pengikut akhir penerima inovasi dalam jaringan namun aspek-aspek adopsi inovasi memiliki skor dalam kategori tinggi. Hal ini dapat dibuktikan sebagai berikut.

Aspek pengetahuan sejak masuk SMK sudah dikenalkan oleh tabungan tabungan "Simpel" iB (Islamic Banking) BPR Syariah Dana Mulia dengan segala macam kelebihan dan manfaat yang akan diperoleh, hal inilah yang membuat aktor \#18 menentukan sikap untuk menerima (persuasi) program tabungan meskipun pada posisi yang paling akhir. Selanjutnya ditindaklanjuti dengan dengan keputusan dan implementasi dalam bentuk berkonsultasi dengan kepala sekolah dan membuka rekening tabungan dengan frekuensi menabung setiap minggu. Hal ini dilakukannya karena aktor \#18 sudah merasakan akan manfaat dari menabung.

\section{Laggards}

Peran Laggards dipegang oleh aktor \#5,\#24,\#25, merupakan orang yang paling akhir mengadopsi inovasi, cirinya adalah ia berperan sebagai pemencil/ isolate dalam jaringan komunikasi. 
Apabila dikaitkan dengan tingkat adopsi inovasi tabungan "Simpel" iB (Islamic Banking) BPR Syariah Dana Mulia yang meliputi pengetahuan, pesuasi, keputusan \& implementasi, dan konfirmasi. Rata-rata tingkat adopsi inovasi masuk dalam kategori sedang.

Jaringan komunikasi pada adopsi inovasi Tabungan "Simpel” iB (Islamic Banking) BPR Syariah Dana Mulia di SMK BATIK 1 Surakarta akan dibahas proses adopsi inovasi dan kategori adopter dalam jaringan siswa SMK Batik1 Surakarta.

\subsection{Proses Adopsi Inovasi Tabungan} "Simpel" iB (Islamic Banking) BPR Syariah Dana Mulia di SMK BATIK 1 SURAKARTA

Keputusan inovasi merupakan sebuah proses dimana seseorang ataupun kelompok memahami sebuah inovasi, membentuk sikap terhadap inovasi, memutuskan untuk menerima inovasi, menerapkan sebuah inovasi dan mengkonfirmasi keputusannya. Sementara adopsi adalah proses keputusan menerima sebuah inovasi beserta apa yang menjadi manfaat dan kerugiannya bagi penerima program. Tahap ini akan ada tiga sikap berkaitan dengan adopsi inovasi tabungan. Sikap pertama siswa akan menerima atau mengadopsi sebuah inovasi tabungan "Simpel" iB BPR Syariah Dana Mulia, sikap kedua siswa tidak langsung menerimanya namun yang mempertimbangkan adanya Inovasi tabungan "Simpel" iB BPR Syariah Dana Mulia, sikap ketiga yaitu menolak inovasi tabungan "Simpel" iB BPR Syariah Dana Mulia. Sehingga untuk mencapai tahap penerimaan diperlukan tahapantahapan yang harus melewati agar terjadi adopsi inovasi tabungan "Simpel" iB BPR Syariah Dana Mulia dapat diterima oleh Siswa..

Tabel. Persentase Siswa SMK BATIK Surakarta dalam Proses Pengambilan Keputusan terhadap Inovasi tabungan "Simpel” iB BPR Syariah Dana Mulia

\begin{tabular}{|l|c|c|c|}
\hline \multicolumn{1}{|c|}{ Proses Pengambilan Keputusan } & Kategori & $\mathrm{f}$ & Persentase \\
\hline Knowledge & Rendah & 0 & 0 \\
\hline & sedang & 5 & 20 \\
\hline Persuasion & Tinggi & 20 & 80 \\
\hline & Rendah & 0 & 0 \\
\hline & sedang & 6 & 24 \\
\hline Decision \& Implementation & Tinggi & 19 & 76 \\
\hline & Rendah & 0 & 0 \\
\hline & sedang & 8 & 32 \\
\hline Konfirmation & Tinggi & 17 & 68 \\
\hline & Rendah & 0 & 0 \\
\hline & sedang & 6 & 24 \\
\hline
\end{tabular}

Sumber: hasil survei, diolah

Dari tabel 4.2 dapat disimpulkan bahwa proses adopsi inovasi pada siswa SMK Batik Surakarta masuk kategori sedang dan tinggi. Terlihat bahwa dalam tahap awal yaitu knowledge (pengetahuan) dimana siswa SMK Batik Surakarta mulai menyadari menyadari adanya inovasi tabungan "Simpel" iB BPR Syariah Dana Mulia, mengetahui fungsi, manfaat dan prasyaratnya, $88 \%$ dari siswa SMK Batik 1 Surakarta masuk dalam kategori tinggi, sementara $12 \%$ anggota kelompok masuk dalam kategori sedang.

Setelah memahami inovasi program tabungan "Simpel” iB BPR Syariah Dana Mulia, tahap yang dilalui selajutnya adalah tahap persuasi (persuasion) dimana dalam tahap ini 
siswa SMK Batik Surakarta mulai menentukan sikap untuk menerima atau tidak inovasi program tabungan "Simpel” iB BPR Syariah Dana Mulia tersebut. $76 \%$ siswa SMK Batik Surakarta menerima atau setuju terhadap tabungan "Simpel" iB BPR Syariah Dana Mulia, namun 24\% siswa SMK Batik Surakarta masih ragu-ragu terhadap inovasi tabungan "Simpel” iB BPR Syariah Dana Mulia.

$68 \%$ siswa SMK Batik Surakarta memilih untuk menerima dan menerapkan apa yang menjadi prasyarat program tabungan "Simpel" iB BPR Syariah Dana Mulia, namun 32\% dari sebagian siswa SMK Batik Surakarta masih ragu untuk menerima inovasi tersebut, alhasil dalam tahap decision atau keputusan mereka meminta nasihat atau pendapat anggota lain sebelum memutuskan untuk menerima program tabungan "Simpel” iB BPR Syariah Dana Mulia tersebut.

Setelah menerapkan sebuah inovasi, pastinya kita akan mengetahui apa manfaat dan kerugiannya sehingga bisa melakukan evaluasi terhadap inovasi tersebut. Dan pada tahap ini kita berhak melakukan konfirmasi, apakah akan tetap menerapkan inovasi tersebut atau sudah cukup. $76 \%$ siswa SMK Batik Surakarta memutuskan untuk tetap menerpkan program tabungan Tabel 4.3 Peran Khusus dalam Adopsi Inovasi Tabungan "Simpel” iB (Islamic Banking) BPR Syariah Dana Mulia di SMK BATIK 1 Surakarta

\begin{tabular}{|c|c|c|}
\hline \multicolumn{3}{|c|}{ Dana Mulia di SMK BATIK 1 Surakarta } \\
\hline Peran & Ciri-ciri & Individu \\
\hline Inovator & $\begin{array}{l}\text { individu yang pertama kali mengadopsi inovasi, cirinya: } \\
\text { komunikator, bukan opinion leader, orang yang pertama } \\
\text { kali membawa inovasi ke dalam system social, berperan } \\
\text { menyampaikan informasi dalam proses difusi. }\end{array}$ & Individu $\# 2, \# 10$ \\
\hline $\begin{array}{l}\text { Early adopter } \\
\text { (pelopor) }\end{array}$ & $\begin{array}{l}\text { individu yang menjadi perintis dalam penerimaan inovasi, } \\
\text { cirinya: opinion leader (pemuka pendapat), orang yang } \\
\text { mempunyai kedudukan dan dihormati dalam kelompok } \\
\text { sosial, mempunyai hubungan komunikasi langsung } \\
\text { dengan innovator. }\end{array}$ & $\begin{array}{l}\text { Individu } \quad \# 9, \quad \# 13, \\
\# 16, \# 22\end{array}$ \\
\hline $\begin{array}{l}\text { Early majority } \\
\text { (pengikut dini) }\end{array}$ & $\begin{array}{l}\text { mayoritas individu pengikut awal dalam penerimaan } \\
\text { inovasi. Cirinya : bukan kelompok pertama yang } \\
\text { mengadopsi, bukan opinion leader, mendapatkan } \\
\text { informasi dari early adopter. }\end{array}$ & $\begin{array}{l}\text { Individu \#1, \#3, \#4, } \\
\# 6, \# 7, \# 8, \# 11, \# 12, \\
\# 15, \# 17, \# 19, \# 20, \\
\# 21, \# 23\end{array}$ \\
\hline Late majority & individu pengikut akhir dalam penerimaan inovasi. & Individu $\quad \# 5, \quad \# 14$, \\
\hline
\end{tabular}

"Simpel" iB BPR Syariah Dana Mulia tersebut, namun $24 \%$ diantaranya masih ragu apakah akan tetap menerapkan atau akan beralih.

\subsection{Kategori Adopter Inovasi Tabungan "Simpel" iB (Islamic Banking) BPR Syariah Dana Mulia di SMK BATIK 1 SURAKARTA}

Dalam proses adopsi inovasi, setiap individu mempunyai waktu dan kecepatan yang berbeda. Menurut Rogers terdapat lima kategori adaptor berdasarkan tingkat keinovatifannya, yakni:

1. Innovator adalah inidividu yang pertama tidak selalu pencetus gagasan baru, tetapi mereka yang memperkenalkan gagasan itu secara luas.

2. Early adopter merupakan adopter awal, biasanya merupakan pemuka pendapat di dalam kelompok.

3. Early majority adalah mayoritas pengikut awal dalam penerimaan inovasi. Cirinya bukan opinion leader dan bukan pula early adopter.

4. Late majority merupakan individu pengikut akhir dalam penerimaan inovasi.

5. Laggards adalah orang yang paling akhir dalam mengadopsi inovasi. mengadopsi inovasi. Namun innovator ini 
Jurnal Ilmiah Ekonomi Islam, 5(03), 2019, 303

\begin{tabular}{|l|l|l|}
\hline \multicolumn{1}{|c|}{ Peran } & \multicolumn{1}{|c|}{ Ciri-ciri } & \multicolumn{1}{|c|}{ Individu } \\
\hline $\begin{array}{l}\text { (pengikut } \\
\text { akhir), }\end{array}$ & $\begin{array}{l}\text { Cirinya: memiliki nilai indeks keterhubungan yang rendah } \\
\text { dibandingkan individu lain. Berperan sebagai neglectee } \\
\text { dalam jaringan komunikasi. }\end{array}$ & \#18,\#24, \#25 \\
\hline $\begin{array}{l}\text { Laggards } \\
\text { (kolot) }\end{array}$ & $\begin{array}{l}\text { merupakan orang yang paling akhir mengadopsi inovasi, } \\
\text { cirinya terisolir berperan sebagai isolate/pemecil dalam } \\
\text { jaringan komunikasi. }\end{array}$ & - \\
\hline
\end{tabular}

Sumber: diolah dari diagram sosiometri siswa SMK 1 Batik Surakarta.

Selain peran khusus individu dalam jaringan komunikasi, dari gambar diagram sosiometri juga dapat dianalisis peran individu di dalam proses adopsi Inovasi Tabungan "Simpel" iB (Islamic Banking) BPR Syariah Dana Mulia di SMK BATIK 1 Surakarta

Peranan-peranan tersebut dalam jaringan komunikasi siswa SMK 1 Batik Surakarta antara lain:

\section{Innovator}

Innovator bukan selalu mereka yang mencetuskan sesuatu yang dianggap inovasi tersebut, namun bisa saja mereka yang memperkenalkan inovasi secara meluas. Di dalam jaringan komunikasi siswa SMK 1 Batik Surakarta yang menjadi innovator adalah individu \#2, \#10 yang merupakan seorang siswi bernama Safira Ardiana Putri yang berumur 16 tahun, pekerjaan orang tuanya sebagai karyawan yang tinggal di rumah kontrakan dengan frekeunsi menabung setiap minggu dengan nominal diatas $\mathrm{Rp} 50.000$.

\section{Early Adopter}

Early adopter atau pelopor awal mempunyai ciri berperan sebagai pemuka pendapat, orang yang mempunya kedudukan dan dihormati dalam jaringan siswa SMK 1 Batik Surakarta yang berperan sebagai early adopter adalah individu \#9, \#13, \#16, \#22. Keduanya adalah seorang siswi yang berumur 16 tahun dengan frekuensi menabung tiap bulan dengan nominal diatas $\mathrm{Rp}$ 50.000 .

\section{Early Majority}

Early majority adalah mayoritas individu pengikut awal dalam penerimaan inovasi, cirinya bukan kelompok pertama yang mengadopsi, bukan opinion leader, mereka yang menerima informasi dari early adopter dalam jaringan siswa SMK 1 Batik Surakarta yang berperan sebagai early majority adalah individu \#1, \#3, \#4, \#6, \#7, \#8, \#11, \#12, \#15, \#17, \#19, \#20, \#21, \#23, merupakan seorang siswi yang berumur 15 tahun dengan frekuensi menbung setiap hari dan pekerjaan orang tuanya sebagai wiraswasta.

4. Late Mjority

Late majority adalah individu pengikut akhir penerima inovasi dalam jaringan siswa SMK 1 Batik Surakarta adalah mereka yang berperan sebagai neglectee, yaitu indivdu \#5, \#14, \#18, \#24, \#25.

5. Laggards

Laggards merupakan orang yang paling akhir mengadopsi inovasi, cirinya adalah ia berperan sebagai pemencil/ isolate dalam jaringan komunikasi. Namun dalam jaringan komunikasi siswa SMK 1 Batik Surakarta tidak terdapat laggards dalam jaringan komunikasi ini.

\subsection{Pengaruh jaringan Komunikasi terhadap adopsi Inovasi}

Penyebaran inovasi dalam system jaringan social terutama di siswa SMA Batik 1 Surakarta dimulai dengan proses komunikasi yang terjadi antara individu individu dalam jaringan melalui system social pertemanan. Individu-invidu berinteraksi dan saling berhubungan dalam proses penyebaran inovasi membentuk jaringan komunikasi yang diduga mempunya pengaruh terhadap tingkat adopsi .

Indikator jaringan komunikasi yang menjadi parameter penelitian ini meliputi: degree, closeness, betweenness, dan eigenvector. Keempat indicator ini diperlakukan sebagai 


\section{Jurnal Ilmiah Ekonomi Islam, 5(03), 2019, 304}

variable independen yang di kaitkan dengan variable dependen yaitu: Knowledge, Persuasion,

Decision \& Implementation, Konfirmation. Metode mengkaitkannya dilakukan dengan analisis regresi linear berganda. Selamjutnya berdasarkan hasil perhitungan dengan program
SPSS versi 20 dipilih uji goodness off fitnya yaitu uji Anova. Uji anova ini (Uji F) berguna untuk mengetahui apakah kebaikan model regresi linear. Berikut ini rekapitulasi hasil perhitungan uji $\mathrm{F}$ tersebut:

Tabel.... Hasil Uji ANOVA (Uji F) variable jaringan dengan variable adopsi inovasi

\begin{tabular}{cllccc}
\hline $\begin{array}{c}\text { Mod } \\
\text { el }\end{array}$ & Independen Variabel & Dependen Variabel & Uji F & $\begin{array}{c}\text { Signifikan } \\
\text { si Model }\end{array}$ & $\begin{array}{c}\text { Jumlah Variabel } \\
\text { yang korelasi } \\
\text { tdk signifikan }\end{array}$ \\
\hline$(1)$ & \multicolumn{1}{c}{$(2)$} & \multicolumn{1}{c}{$(3)$} & $(4)$ & $(5)$ & $(6)$ \\
\hline 1 & Indikator Jaringan & Knowledge & 8,400 & 0,000 & 0 \\
2 & (Degree, Closeness, & Persuasion & 8,702 & 0,000 & 0 \\
3 & Betweenness, & Decision \& Implementation & 5,664 & 0,003 & 0 \\
4 & Eigenvector) & Konfirmation & 7,977 & 0,001 & 0 \\
\hline
\end{tabular}

Keempat model regresi menunjukkan hasil yang signifikan pada tingkat kepercayan $5 \%$. Hasil uji F menunjukkan bahwa semua indicator jaringan (variable independen)adalah signifikan secara agregat berpengaruh terhadap setiap proses adopsi inovasi (variable dependen) .
Demikian juga dengan analisis matrix korelasi yang terbentuk untuk setiap model regresi juga menunjukkan adanya tingkat signifikansi yang meyakinkan yaitu di bawah $5 \%$.

Correlations

\begin{tabular}{|ll|c|c|c|c|}
\hline & & Pgth & Pss & KI & KF \\
\hline \multirow{5}{*}{ Degree } & Pearson Correlation &, 731 &, 549 &, 470 &, 489 \\
& Sig. (2-tailed) &, 000 &, 004 &, 018 &, 013 \\
& df & 25 & 25 & 25 & 25 \\
& Pearson Correlation &, 642 &, 655 &, 658 &, 499 \\
Closeness & Sig. (2-tailed) &, 001 &, 000 &, 000 &, 011 \\
& df & 25 & 25 & 25 & 25 \\
& Pearson Correlation &, 670 &, 474 &, 456 &, 533 \\
Betweenness & Sig. (2-tailed) &, 000 &, 017 &, 022 &, 010 \\
& df & 25 & 25 & 25 & 25 \\
& Pearson Correlation &, 713 &, 594 &, 512 &, 602 \\
Eigenvector & Sig. (2-tailed) &, 000 &, 002 &, 009 &, 001 \\
& df & 25 & 25 & 25 & 25 \\
\hline
\end{tabular}

Berdasarkan hasil matrik korelasi tersebut menunjukkan bahwa variable dependen (proses adopsi inovasi) yang meliputi Knowledge, Persuasion, Decision \& Implementation, Konfirmation berkoralasi positif dengan indicator system jaringan (variable independen) yaitu Degree, Closeness, Betweenness, Eigenvector

3.6. Hubungan jaringan komunikasi dengan tingkat keinovatifan adopter dalm proses adopsi inovasi

Menurut Hanafi (2007) bahwa anggot system dalam jaringan yang lebih inovatif biasa 
lebih banyak mencari informasi mengenai inovasi. Dengan kata lain, mereka yang lebih inovatif biasanya akan lebih berperan di dalam jaringan komunikasi. Penelitian ini berusaha untuk membuktikan secara empiris bahwa variable jaringan komunikasi berpengaruh terhadap tingkat keinovatifan anggota dalm proses adopsi inovasi.

Nilai keempat indicator jaringan dan kategori adopter adalah signifikan padalevel tingkat kepercayaan $\alpha=0,05$ (5\%). Hal ini menunjukkan adanya hubungan yang signifikan antara peran aktor dalam jaringan dengan tingkat keinovaifan anggota jaringan.

Seorang star dalam jaringan komunikasi secara umum juga berperan sebagai aktor yang paling awal mengadopsi inovasi. Pada kelompok jaringan siswa SMK 1 Batik Surakarta terdapat 2 (dua) orang star dalam jaringan adopsi Inovasi Tabungan "Simpel" iB (Islamic Banking) BPR Syariah Dana Mulia. Orang -orang dalam kategori star telah mengadopsi Inovasi Tabungan "Simpel" iB (Islamic Banking) BPR Syariah Dana Mulia lebih dulu sebelum sekolah dan BPR Dana Mulia memperkenalkan produk tabungan "Simpel" kepada siswa yang lainnya, bahkan mereka sudah menjadi inisaator untuk program menabung bagi teman-temannya.

Sebagai inisiator dalam kegiatan menabung di Tabungan "Simpel” iB (Islamic Banking) BPR Syariah Dana Mulia tampak dari kedekatan mereka dengan manajemen BPR Syariah Dana Mulia. Secara factual para aktor ini juga telah melakukan kegiatan menabung dengan besaran diatas Rp 50.000 per minggu dan ini merupakan uang saku yang diberikan orang tua yang tidak dikonsumsi bahkan ditabung dengan cara dikumpulkan setiap hari maka setelah satu minggu di tabungkan. Hal ini menunjukkan sikap keseriusan aktor dalam mengimplementasikan pengetahuan yang dimilikinya tentang manfaat menabung.

\section{Kesimpulan}

Setelah dilakukan analisis, dapat disimpulkan bahwa proses adopsi inovasi siswa SMK Batik Surakarta masuk kategori sedang dan tinggi. Terlihat bahwa dalam tahap awal yaitu knowledge (pengetahuan) dimana anggota siswa SMK Batik Surakarta mulai menyadari menyadari adanya inovasi Program tabungan "Simpel" iB BPR Syariah Dana Mulia, mengetahui fungsi, manfaat dan prasyaratnya, $88 \%$ dari siswa SMK Batik Surakarta masuk dalam kategori tinggi, sementara $12 \%$ anggota kelompok masuk dalam kategori sedang. Setelah memahami inovasi tabungan "Simpel" iB BPR Syariah Dana Mulia, tahap yang dilalui selajutnya adalah tahap persuation (persuasi) dimana dalam tahap ini siswa SMK batik Surakarta mulai menentukan sikap untuk menerima atau tidak inovasi program tabungan "Simpel” iB BPR Syariah Dana Mulia tersebut. $76 \%$ siswa SMK Batik 1 Surakarta menerima atau setuju terhadap inovasi tabungan "Simpel" iB BPR Syariah Dana Mulia, namun 24\% siswa SMK Batik 1 Surakarta masih ragu-ragu terhadap inovasi tabungan "Simpel" iB BPR Syariah Dana Mulia. 68\% siswa SMK Batik 1 Surakarta memilih untuk menerima adanya program tabungan "Simpel" iB BPR Syariah Dana Mulia, namun 32\% dari anggota kelompok masih ragu untuk menerima inovasi tersebut, alhasil dalam tahap decision dan implementasi mereka meminta nasihat atau pendapat anggota lain sebelum memutuskan untuk menerima program tabungan "Simpel" iB BPR Syariah Dana Mulia tersebut. Setelah menerapkan sebuah inovasi, pastinya kita akan mengetahui apa manfaat dan kerugiannya sehingga bisa melakukan evaluasi terhadap inovasi tersebut. Dan pada tahap ini kita berhak melakukan konfirmasi, apakah akan tetap menerapkan inovasi tersebut atau sudah cukup. 76\% siswa SMK Batik 1 Surakarta memutuskan untuk tetap menggunakan program tabungan "Simpel" iB BPR Syariah Dana Mulia tersebut, namun 24\% diantaranya masih ragu apakah akan tetap menggunakan atau akan beralih. 


\section{Ucapan Terimakasih}

Segala puji syukur kehadirat Allah SWT atas petunjuk dan rahmat yang diberikan, sehingga penulis dapat menyelesaikan naskah jurnal dengan judul JARINGAN KOMUNIKASI TENTANG ADOPSI INOVASI TABUNGAN "SIMPEL" iB (ISLAMIC BANKING) SMK BATIK 1 SURAKARTA (Analisis Jaringan Komunikasi Tabungan "Simpe" iB BPR Syariah Dana Mulia di SMK Batik 1 Surakarta Kelas AUK 1.A). Pada kesempatan ini penulis mengucapkan terima kasih kepada Drs.Prahastiwi Utari, M.Si, Ph.D, Dekan Program studi Magister Ilmu Komunikasi Pascasarjana Universitas Sebelas Maret. Dr.Sutopo, M.S Pembimbing I, yang telah berkenan meluangkan waktu untuk membimbing dan memberikan arahan dalam pembuatan thesis ini. Drs.Ign.Agung Satyawan, SE,S.I.Kom, M.si,Ph.D Pembimbing II, yang berkenan meluangkan waktu untuk membimbing dan memberikan arahan dalam pembuatan thesis ini. Kedua Orang tua saya Bapak Ir. Drs. H. Mardiyono dan Hj.Ibu Tri Winarsih yang telah memberikan kesempatan untuk menimba Ilmu, memberi restu, dorongan, semangat dan doa yang terbaik kepada penulis hingga dapat menyelesaikan studi di program Pascasarjana Ilmu Komunikasi UNS. Semua Pihak yang telah membantu selama menjalani pendidikan penelitian maupun menjalani pendidikan di Magister Ilmu Komunikasi UNS.

\section{Daftar Pustaka}

Babbie, Earl , 2014, The Practice of Social Research, Fifth Edition, California Wadswoth Publishing Company Inc

Dwi Narwoko, J., dan Suyanto, Bagong., Sosiologi Teks Pengantar Dan Terapan. Jakarta : Kencana. 2011.

Everett M. Rogers. 1983. Diffusion of Innovations. London: The Free Press.

Hanafi, Mamduh H dan A. Halim. 2007. Analisis Laporan Keuangan, edisi 3. Yogyakarta : Penerbit UPP STIM YKPN.

Harold D. Lasswell 2009 Structure an Function of Communication in Societ dalam. Wilbur Schramm. (Ed)
Kincaid, Lawrence dan Schramm, Wilbur. 1977. Asas-asas Komunikasi Antar Manusia (terjemahan; Agus Setiadi). Jakarta: LP3ESEWCI

Knoke, David and James Kulkinskni, 1982. Network Analysis. London: Sage Publication. Kotler, philip, 2007, Manajemen Pemasaran, Jilid 2, Edisi 12, PT Indeks, New Jersey

Mardikanto, Totok, 2009. Sistem Penyuluhan Pertanian. Universitas Sebelas Maret. Surakarta.467 Hal.

Monge, P. R., \& Contractor, N. (2003) Theories of Communication networks : Oxford: University press

Mulyana, Dedi. 2001. Ilmu Komunikasi, Suatu Pengantar. Bandung: Remaja Rosdakarya.

Padje, Gud Recht Hayat. 2008. Komunikasi Kontemporer: Strategi, Konsepsi, dan Sejarah. Kupang: Universitas PGRI.

Rogers, Everett M., 1983, Diffusion of Innovations. London: The Free Press.

Rogers, Everret M., \& D. Lawrence Kincaid .1981. Communication Networks. Toward a New Paradigm for Reseach. New York: The Free Press.

Rusady, Ruslan, 2004, Manajemen Public Relation dan Media Komunikasi, Edisi Revisi ke-7, PT. Raja Grafindo Persada, Jakarta.

Schramm, Wilbur. (1997). Big Media, little media, tools and technologies for instructtion. London : Sage Publications

Setiawan dan Kusrini, D. E., dan. 2010. Ekonometrika. Yogyakarta: Andi.

Soekartawi. (1998). Prinsip Dasar Ekonomi Pertanian. UI Press. Jakarta.

Sugiarto, dkk. 2003. Teknik Sampling. Jakarta : PT Gramedia Pustaka Utama

Sumarwan, Ujang, Perilaku Konsumen : Teori dan Penerapannya Dalam Pemasaran, Penerbit Ghalia Indonesia, Bogor, 2011

Zulfikar, 2013, Pola Jaringan Komunikasi Kelompok Dalam Menumbuhkan Solidaritas Aksi Unjuk Rasa Mahasiswa Di Kota Makassar, tesis, Program Pascasarjana Universitas Hasanuddin Makassar 